\title{
Effect of pH and Calcium Concentration on Some Textural and Functional Properties of Mozzarella Cheese
}

\author{
T. P. Guinee, ${ }^{\star}$ E. P. Feeney, $†$ M. A. E. Auty, ${ }^{\star}$ and P. F. Fox $\dagger$ \\ *Dairy Products Research Centre, \\ Teagasc Moorepark, Fermoy, Co. Cork, Ireland \\ †Food Chemistry, \\ Department of Food Science, Technology and Nutrition, \\ University College, Cork, Ireland
}

\begin{abstract}
The effects of Ca concentration and $\mathrm{pH}$ on the composition, microstructural, and functional properties of Mozzarella cheese were studied. Cheeses were made using a starter culture (control) or by direct acidification of the milk with lactic acid or lactic acid and glucono$\delta$-lactone. In each of three trials, four cheeses were produced: a control, CL, and three directly-acidified cheeses, DA1, DA2, and DA3. The cheeses were stored at $4^{\circ} \mathrm{C}$ for $70 \mathrm{~d}$. The $\mathrm{Ca}$ content and $\mathrm{pH}$ were varied by altering the $\mathrm{pH}$ at setting, pitching, and plasticization. The mean $\mathrm{pH}$ at $1 \mathrm{~d}$ and the Ca content ( $\mathrm{mg} / \mathrm{g}$ of protein) of the various cheeses were: CL, 5.42 and 27.7; DA1, 5.96 and 21.8; DA2, 5.93 and 29.6; DA3, 5.58 and 28.7. For cheeses with a high $\mathrm{pH}$ (i.e., $\sim 5.9$ ), reducing the $\mathrm{Ca}$ content from 29.6 to $21.8 \mathrm{mg} / \mathrm{g}$ of protein resulted in a significant decrease in the protein level and increases in the moisture content and mean level of nonexpressible serum (g/g of protein). Reducing the Ca concentration also resulted in a more swollen, hydrated para-casein matrix at $1 \mathrm{~d}$. The decrease in Ca content in the high$\mathrm{pH}$ cheeses coincided with increases in the mean stretchability and flowability of the melted cheese over the 70-d storage period. The fluidity of the melted cheese also increased when the Ca content was reduced, as reflected by a lower elastic shear modulus and a higher value for the phase angle, $\delta$, of the melted cheese, especially after storage for $<12 \mathrm{~d}$. The melt time, flowability, and stretchability of the low-Ca, high-pH DA1 cheese at $1 \mathrm{~d}$ were similar to those for the CL cheese after storage for $\geq 12 \mathrm{~d}$. In contrast, the mean values for flowability and stretchability of the high-pH, highCa DA2 cheese over the 70-d period were significantly lower than those of the CL cheese. Reducing the $\mathrm{pH}$ of high-Ca cheese (27.7 to $29.6 \mathrm{mg} / \mathrm{g}$ of protein) from $\sim 5.95$
\end{abstract}

Received May 21, 2001.

Accepted January 28, 2002.

Corresponding author: Timothy P. Guinee; e-mail: tguinee@ moorepark.teagasc.ie. to 5.58 resulted in higher flowability, stretchability, and fluidity of the melted cheese. For cheeses with similar $\mathrm{pH}$ and $\mathrm{Ca}$ concentration, the method of acidification had little effect on composition, microstructure, flowability, stretchability, and fluidity of the melted cheese. (Key words: $\mathrm{pH}$, calcium $(\mathrm{Ca})$, Mozzarella, texture, and functionality)

Abbreviation key: $\mathbf{A V}=$ maximum apparent viscosity, $\mathbf{C L}=$ control, $\mathbf{C P}=$ curd particle, $\mathbf{C P M}=$ curd particle membrane, CSLM = confocal scanning laser microscopy, $\delta=$ phase angle, $\mathbf{D A}=$ directly-acidified, $\mathbf{F D M}=$ fat-in-dry matter, $\mathbf{G}^{\prime}=$ elastic shear modulus, $\mathbf{G D L}=$ glucono- $\delta$-lactone, MNFS = moisture-in-nonfat-substance, $\mathbf{N E S}=$ nonexpressible serum, $\mathbf{N E S C}=$ nonexpressible serum in $\mathrm{g} / 100 \mathrm{~g}$ of cheese; NESP $=$ nonexpressible serum in $\mathrm{g} / \mathrm{g}$ of protein in cheese, WHC = water-holding capacity.

\section{INTRODUCTION}

Global production of Mozzarella cheese has grown dramatically during the period 1985 to 2000 (Rowney et al., 1999), especially in the United States, where annual production in 1996 was $\sim 1.03$ million tonne (Sørensen, 1997). The main impetus for the growth of Mozzarella has been the ubiquitous increase in the popularity of pizza, in which Mozzarella is the main cheese used. The functional attributes of importance for pizza include the desired degrees of flow and stringiness on baking. The cheeses best endowed with these characteristics, especially stretchability, are members of the pasta filata group and include Mozzarella, Provolone, and Kashkaval (Fox et al., 2000). In the manufacture of these cheeses, the fermented curd ( $\mathrm{pH} \sim 5.1$ to 5.4 ) is subjected to a plasticization step towards the end of manufacture during which it is scalded (to $\sim 57^{\circ} \mathrm{C}$ ), kneaded, and stretched in hot $\left(\sim 80^{\circ} \mathrm{C}\right)$ water or dilute brine. The conditions of low $\mathrm{pH}$ and high temperature are conducive to limited aggregation of para-casein and the formation of para-casein fibers of relatively high tensile strength (Kimura et al., 1992; Taneya et al., 
1992). These fibers impart stretchability, stringiness, and chewiness to the melted cheese topping when the cheeses are subsequently cooked on pizza (Fox et al., 2000).

It is generally accepted that $\mathrm{pH}$ and Ca concentration influence the ability of curd to plasticize in hot water or hot dilute brine. Hence, in the typical conventional manufacture of pasta filata cheeses, the curd $\mathrm{pH}$ is allowed to decrease, via the conversion of lactose to lactic acid, to a value typically in the range $\sim 5.4$ to $\sim 5.1$ before plasticization. The reduction in curd $\mathrm{pH}$ promotes a number of physico-chemical conditions, which are conducive to the flow of the curd during plasticization: solubilization of micellar calcium phosphate (van Hooydonk et al., 1986), an increase in the ratio of soluble to colloidal Ca (Guinee et al., 2000a), and an increase in para-casein hydration (Creamer, 1985). Generally, at $\mathrm{pH}$ values $>\sim 5.4$, it is more difficult to plasticize the curd (Kimura et al., 1992); the curd becomes progressively less smooth and more lumpy with increasing $\mathrm{pH}$. However, curd may be plasticized successfully at a higher pH (e.g., 5.6) and higher colloidal to soluble $\mathrm{Ca}$ ratio if the total concentration of $\mathrm{Ca}$ is lower than that in curd made by the traditional procedure, e.g., as in directly acidified Mozzarella, where the milk is setting at $\mathrm{pH} \sim 5.6$ (Keller et al., 1974; Kindstedt and Guo, 1997a).

The functional attributes of Mozzarella cheese are influenced by many factors, including milk pretreatment, make procedure, composition, and proteolysis (Lawrence, 1989; McMahon et al., 1993; Kindstedt, 1995; Madsen and Qvist, 1998). Comparatively little information is available on the effects of $\mathrm{pH}$, and $\mathrm{Ca}$ content, and their interaction on the functional attributes of plasticized cheese (e.g., Mozzarella) when cooked on pizza (McMahon et al., 1993; McMahon and Oberg, 1999; Rowney et al., 1999). Keller et al. (1974) reported a significant negative correlation between the Ca concentration in DM and the flowability of directly acidified Mozzarella. Kimura et al. (1992) found that increasing the $\mathrm{pH}$ at curd plasticization from 5.2 to 5.5 resulted in a decrease in the stringiness of unheated string cheese. Increasing the Ca content of Mozzarella (from 27.2 to $29.6 \mathrm{mg} / \mathrm{g}$ of protein), by increasing the $\mathrm{pH}$ at whey drainage from 6.15 to 6.4 resulted in a slight decrease in moisture content from 46.3 to $45.7 \%$ (wt/wt) but did not significantly affect the final $\mathrm{pH}$ or the apparent viscosity, level of free oil, or flowability during storage (Yun et al., 1995).

The objective of the current study was to investigate the effects of $\mathrm{Ca}$ content and $\mathrm{pH}$ and their interaction on the texture and heat-induced functionality of Mozzarella cheese.

\section{MATERIALS AND METHODS}

\section{Cheese Manufacture}

In each of three trials, four types of Mozzarella cheese were manufactured, using either a starter culture, as in conventional manufacture of the control cheese (CL), or by direct acidification (DA), using lactic acid (directly acidified cheese, DA1), or a combination of lactic acid and glucono- $\delta$-lactone (GDL; directly acidified cheeses DA2 and DA3). The four cheeses differed with respect to $\mathrm{pH}$ of milk at rennet addition (setting), $\mathrm{pH}$ of the curd at whey drainage, and $\mathrm{pH}$ of the curd at milling and plasticization (Table 1).

Cheesemaking was performed in cylindrical, jacketed, 500-L stainless steel vats with automated variable-speed cutting and stirring (APV Schweiz AG, CH3076 Worb 1, Switzerland). The CL cheese was manufactured by a dry salting procedure, as described by Guinee et al. (2000b). Milk (450 L) was inoculated with a starter culture, consisting of Streptococcus thermophilus and Lactobacillus helveticus. Chymosin (Double Strength Chy-max, 50,000 milk clotting units/ml; Pfizer, Inc., Milwaukee, WI) was added at a level of $0.077 \mathrm{ml} / \mathrm{kg}$ of milk at $36^{\circ} \mathrm{C}$. The coagulum was cut when it attained a firmness sufficient to withstand cutting, as assessed subjectively by the cheesemaker. After cutting ( 39 min later), the curds-whey mixture was allowed to heal for $6 \mathrm{~min}$ and then stirred continuously, with the speed of stirring increasing gradually from 10 to $22 \mathrm{rpm}$ over $30 \mathrm{~min}$. The curds-whey mixture was cooked to $42^{\circ} \mathrm{C}$, at a rate of $1^{\circ} \mathrm{C} / 5 \mathrm{~min}$, and continually stirred until the $\mathrm{pH}$ of the curd decreased to 6.1. The curd was then pumped to rectangular, jacketed 500$\mathrm{L}$ stainless steel finishing vats (warmed to $40^{\circ} \mathrm{C}$ by circulating water), where the curds-whey mixture was allowed to settle for $2 \mathrm{~min}$ before drainage of the whey.

After whey drainage, the curds $(\sim 52 \mathrm{~kg})$ were cheddared in the finishing vat and milled at $\mathrm{pH} 5.15$ (to a chip size of $\sim 2.8 \times 1.25 \times 1.25 \mathrm{~cm}$ ). The $\mathrm{pH}$ of the curd $\left(\sim 39^{\circ} \mathrm{C}\right)$ at milling was measured by inserting the $\mathrm{pH}$ probe (calibrated at $39^{\circ} \mathrm{C}$ ) directly into the curd. The milled curd was dry salted at a level of $4.6 \%$ (wt/wt), mellowed for $20 \mathrm{~min}$, and transferred to the stretching unit (Automatic Stretching Machine, Model d; CMT, S. Lorenzo di Peveragno CN, Italy). The curd was heated to $58^{\circ} \mathrm{C}$ by dousing with hot water at $78^{\circ} \mathrm{C}$ (used at a level of $\sim 1.4 \mathrm{~kg} / \mathrm{kg}$ of curd and added over a period of $8 \mathrm{~min}$ ) and batch plasticized mechanically. The molten plastic curd mass was then conveyed by auger to the molding unit where it was formed into a cylindrical mass which was guillotined into $2.3-\mathrm{kg}$ portions (24$\mathrm{cm}$ long). The portions were deposited, in a horizontal orientation, into rectangular molds of the same length; after $1 \mathrm{~min}$, the hot curd in the mold was manually 
Table 1. Treatments and details of the manufacturing process of experimental Mozzarella cheeses. ${ }^{1}$

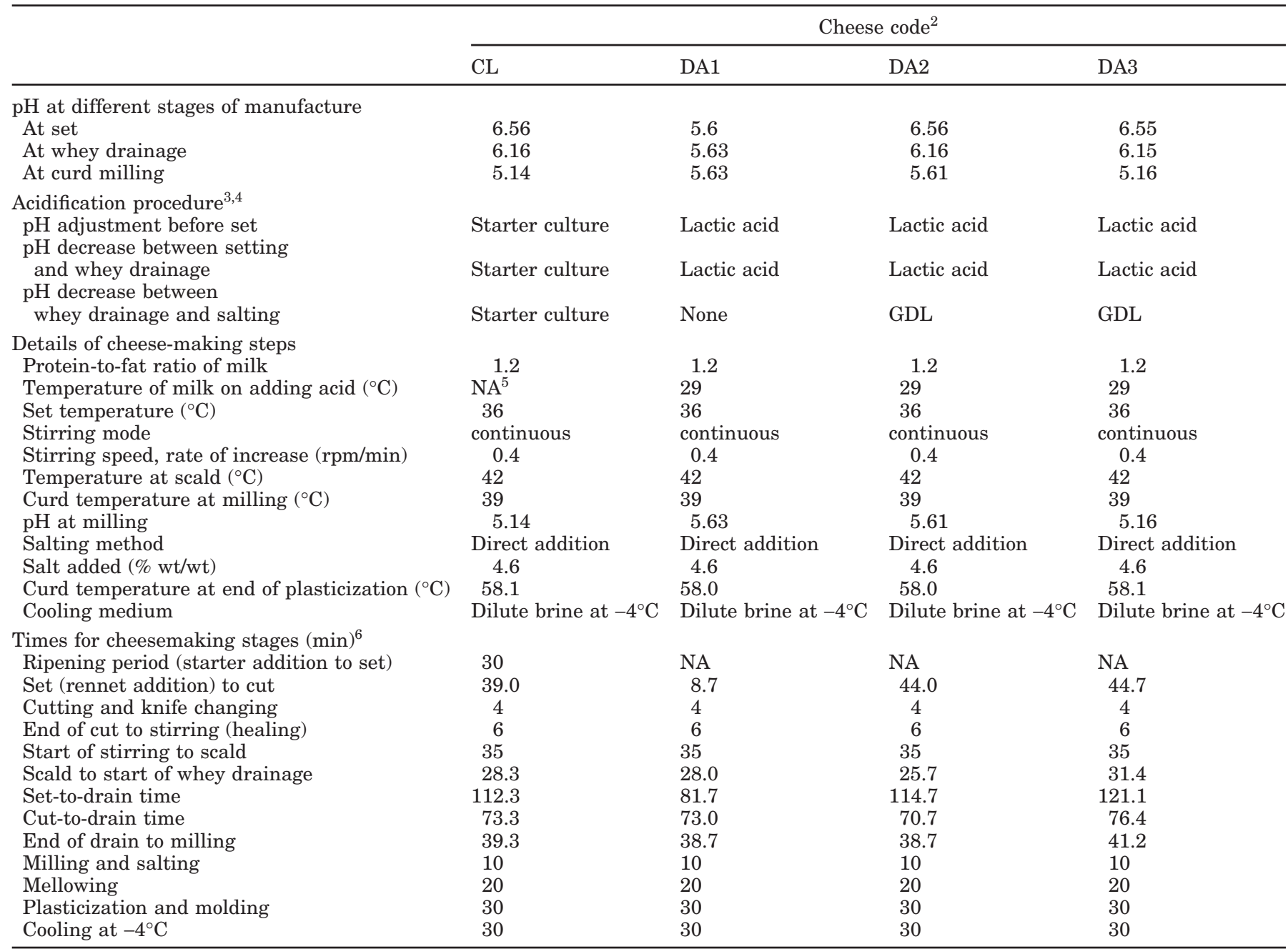

\footnotetext{
${ }^{1}$ Details of cheese manufacture are given in text.

${ }^{2}$ Cheeses were produced using a starter culture as in conventional manufacture (CL) or by direct acidification (DA) using lactic acid (DA1) or a combination of lactic acid and glucono- $\delta$-lactone (DA2 and DA3).

${ }^{3}$ Dilute lactic acid solution $(5 \mathrm{~g} / 100 \mathrm{ml})$ was prepared by diluting concentrated lactic acid $(80 \mathrm{~g} / 100 \mathrm{ml})$ with distilled water.

${ }^{4} \mathrm{GDL}$, glucono- $\delta$-lactone was dry blended with the salt prior to addition to the cheese curd, which was milled twice to a final chip size of $\sim 3 \mathrm{~cm} \times 2 \mathrm{~cm} \times 2 \mathrm{~cm}$.

${ }^{5} \mathrm{NA}$, not applicable.

${ }^{6}$ Values given are the means of the three trials.
}

turned to facilitate the molding of the curd to the rectangular shape. This filling procedure ensured that the orientation of the cheese fibers in of the molded curd was similar to that in curd on discharge from the molding unit. The molds containing the curds were then placed in dilute brine $(10 \mathrm{~g}$ of $\mathrm{NaCl} / 100 \mathrm{~g}, 0.2 \mathrm{~g}$ of $\mathrm{Ca} /$ $100 \mathrm{~g}, \mathrm{pH} 5.1$ ) at $\sim-4.0^{\circ} \mathrm{C}$ for $30 \mathrm{~min}$ to cool the block of curd to a surface temperature of $24^{\circ} \mathrm{C}$ and a core temperature of $<45^{\circ} \mathrm{C}$. The cheeses, 14 per vat, were then removed from the molds, allowed to drip dry for $10 \mathrm{~min}$ at room temperature, and vacuum wrapped and stored at $4^{\circ} \mathrm{C}$.
The details for manufacture of the different cheeses are shown in Table 1. Apart from differences in the $\mathrm{pH}$ at setting, whey drainage and plasticization, the manufacturing procedure for the DA cheese was similar to that for the control cheese in terms of cutting (firmness at initiation of cutting, speed, and duration), stirring (speed and duration), cooking rate, cheddaring time, mellowing time, plasticization, molding, and cooling (Table 1). For the manufacture of DA1 Mozzarella, the milk $\left(36^{\circ} \mathrm{C}\right)$ was acidified directly to $\mathrm{pH} 5.6$ with lactic acid $(5 \mathrm{~g} / 100 \mathrm{ml}$; (Wardle Chemicals, Calveley, Nr. Tarporley, Cheshire, UK). The cheese-making pro- 
cedure was otherwise similar to that for the CL cheese, apart from the differences in $\mathrm{pH}$ at setting, whey drainage, and salting (Table 1).

In the manufacture of DA2 and DA3 cheeses, milk was acidified with lactic acid (5\%, wt/vol), which was added at a rate designed to simulate the $\mathrm{pH}$ profile of the CL Mozzarella to the point of whey drainage. After whey drainage, GDL powder (ADM, Ringaskiddy, Cork, Ireland) was mixed with the salt and added to the curd to reduce the $\mathrm{pH}$ to the desired value, at levels of 1.6 $\mathrm{g} / 100 \mathrm{~g}$ or $3.6 \mathrm{~g} / 100 \mathrm{~g}$ for the DA2 and DA3 cheeses, respectively. Treatment of the curd after salting in the manufacture of the DA2 and DA3 cheeses was similar to that for the control. Preliminary bench-scale cheesemaking studies were undertaken to establish the levels of lactic acid and GDL required to reduce the $\mathrm{pH}$ of the DA curds to the appropriate values at the different stages of manufacture.

\section{Sampling of Cheese}

The cheeses were sampled and prepared, as described by Guinee et al. (2000c), to give grated particles $(<1$ $\mathrm{mm}$ ), shreds ( $\approx 25$-mm long and $\approx 4$-mm diam), discs $(6.5$ $\mathrm{mm}$ thick and $45.5-\mathrm{mm}$ diam or $2.0-\mathrm{mm}$ thick and 41 $\mathrm{mm}$ diam), and cylinders (29-mm high and 29-mm diam).

\section{Composition and Proteolysis}

Grated cheeses were analyzed in duplicate for salt, fat, protein, moisture, and $\mathrm{pH}\left(\right.$ at $22^{\circ} \mathrm{C}$ ), $\mathrm{Ca}$, phosphorus, and $\mathrm{pH} 4.6$-soluble $\mathrm{N}$, as described by Guinee et al. $(2000 \mathrm{c})$. The level of intact casein $(\mathrm{g} / 100 \mathrm{~g})$ in the cheese was calculated using the formula:

$$
\begin{gathered}
\text { Intact casein }=6.38 \times[\text { Total } \mathrm{N}(\mathrm{g} / 100 \mathrm{~g}) \\
-\mathrm{pH} 4.6 \text {-soluble } \mathrm{N}(\mathrm{g} / 100 \mathrm{~g})] .
\end{gathered}
$$

It was assumed that all the protein in the cheese was casein.

\section{Confocal Scanning Laser Microscopy (CSLM)}

Cheeses from the three trials were examined by confocal scanning laser microscopy (CSLM) at 1 and $20 \mathrm{~d}$, as described by Guinee et al. (1999). Cheese was cut into 4-cm cubes. One edge of each cube was pulled apart manually. This revealed the fibrous nature of the cheese and enabled sections to be cut parallel to the fiber direction. Sections of cheese, approximately $10 \times 10 \times 2 \mathrm{~mm}$ thick, were cut from a freshly cut cube with a razor blade (at $4^{\circ} \mathrm{C}$ ). This sampling technique ensured that the fibers in the sections had a longitudinal orientation.
The sections were stained with $0.1 \%$ (wt/vol) aqueous Nile blue A (C.I. 51180 sulphate salt; Sigma Chemical Co., Poole, Dorset, UK), and examined with a Zeiss LSM310 confocal scanning laser microscope (Carl Zeiss, Ltd., Welwyn Garden City, Herts., UK). Representative images were acquired at both 488 and $633 \mathrm{~nm}$ to enable direct comparison of the distribution and microstructure of the fat and protein, respectively; stained regions appear bright against a dark background.

\section{Cheese Firmness}

Four to six cylindrical samples were taken from each cheese, placed in an airtight plastic bag, held at $8^{\circ} \mathrm{C}$ overnight and compressed to $30 \%$ of original height on a model 112 Universal Instron Testing Machine (Instron, Ltd., High Wycomb, UK), as described by Guinee et al. (2000c). Firmness was the force required to compress the samples of cheese to $30 \%$ of the original height.

\section{Expressible Serum}

Cheese serum was expressed by centrifugation of grated cheese at $12,500 \times g$ at $20^{\circ} \mathrm{C}$, as described by Kindstedt and Guo (1997a). The expressed serum and fat were collected in a preweighed graduated cylinder that was held at $4^{\circ} \mathrm{C}$ until the surface layer of fat had solidified. The solidified fat layer was punctured to release the subnatant serum, which was poured off and weighed.

\section{Evaluation of Cheese Functionality on Cooking}

Melt time was defined as the time required for a fixed weight of shredded cheese $\left(1.73 \mathrm{~kg} / \mathrm{m}^{2}\right)$ to melt and fuse into a molten mass, free of shred identity, on heating at $280^{\circ} \mathrm{C}$ (Guinee et al., 2000a, 2000c). Flowability was defined as the percentage increase in the diameter of a disk of cheese ( $45 \mathrm{~mm}$ diameter, $6.5 \mathrm{~mm}$ thick) on melting at $280^{\circ} \mathrm{C}$ for $4 \mathrm{~min}$ (Guinee et al., 2000a, 2000c). The stretchability of the molten cheese on baked pizza was measured by uniaxial extension at a velocity of $0.066 \mathrm{~m} / \mathrm{s}$ (Guinee et al., 2000a, 2000c); before heating, the shredded cheese was distributed uniformly at a fixed loading $\left(2.5 \mathrm{~kg} / \mathrm{m}^{2}\right)$ onto a pizza base that was precut in half. The maximum apparent viscosity (AV) of the molten cheese (at $70^{\circ} \mathrm{C}$ ) was measured using a helipath viscometry (Brookfield Model DV-II Visometer; Brookfield, Engineering Labs., Stoughton, MA) as described by Guinee et al. (2000a, 2000c).

\section{Viscoelastic Changes during Heating}

Changes in the viscoelasticity of the cheese on heating from 20 to $80^{\circ} \mathrm{C}$ were measured by low amplitude 
Table 2. Composition of low-moisture Mozzarella cheeses made using different procedures and with different $\mathrm{pH}$ and calcium level. Values presented are the means of three replicates. ${ }^{1}$

\begin{tabular}{lccccc}
\hline & \multicolumn{4}{c}{ Cheese Code } & \\
\cline { 2 - 5 } Composition & CL & DA1 & DA2 & DA3 & SED $^{3}$ \\
\hline Moisture (\% wt/wt) & $48.00^{\mathrm{b}}$ & $56.73^{\mathrm{a}}$ & $49.35^{\mathrm{b}}$ & $50.78^{\mathrm{b}}$ & 1.62 \\
Fat $\% \mathrm{wt} / \mathrm{wt})$ & $20.33^{\mathrm{a}}$ & $15.94^{\mathrm{b}}$ & $16.89^{\mathrm{b}}$ & $16.16^{\mathrm{b}}$ & 1.02 \\
Protein $\% \mathrm{wt} / \mathrm{wt})$ & $27.00^{\mathrm{a}}$ & $23.52^{\mathrm{b}}$ & $28.51^{\mathrm{a}}$ & $27.61^{\mathrm{a}}$ & 0.79 \\
MNFS $(\% \mathrm{wt} / \mathrm{wt})^{2}$ & $60.25^{\mathrm{b}}$ & $67.43^{\mathrm{a}}$ & $59.38^{\mathrm{b}}$ & $60.57^{\mathrm{b}}$ & 1.26 \\
FDM (\% wt/wt) & $39.09^{\mathrm{a}}$ & $36.77^{\mathrm{a}}$ & $33.34^{\mathrm{b}}$ & $32.86^{\mathrm{b}}$ & 1.09 \\
S/M (\% wt/wt) & $3.32^{\mathrm{a}}$ & $2.96^{\mathrm{a}}$ & $3.54^{\mathrm{a}}$ & $3.07^{\mathrm{a}}$ & 0.26 \\
Ash (\% wt/wt) & $3.57^{\mathrm{a}}$ & $3.00^{\mathrm{b}}$ & $4.02^{\mathrm{a}}$ & $3.10^{\mathrm{a}}$ & 0.19 \\
Ca (mg/g protein) & $27.7^{\mathrm{a}}$ & $21.8^{\mathrm{b}}$ & $29.6^{\mathrm{a}}$ & $28.7^{\mathrm{a}}$ & 1.42 \\
pH at 1 d & $5.42^{\mathrm{b}}$ & $5.96^{\mathrm{a}}$ & $5.93^{\mathrm{a}}$ & $5.58^{\mathrm{b}}$ & 0.10 \\
\hline
\end{tabular}

${ }^{\mathrm{a}, \mathrm{b}}$ Values within a row not sharing a common superscript differed $(P<0.05)$.

${ }^{1}$ Differences in make procedure for the different cheeses are given in Table 1.

${ }^{2} \mathrm{MNFS}=$ Moisture-in-nonfat-substance; FDM = fat-in-DM; S/M = salt-in-moisture.

${ }^{3} \mathrm{SED}=$ Standard error of difference.

strain oscillation in a controlled stress rheometer $\left(\mathrm{CSL}^{2}{ }_{500}\right.$ Carri-Med; TA Instruments, Inc., New Castle, $\mathrm{DE})$, as described by Guinee et al. (1999). Disks (41$\mathrm{mm}$ diameter, $2 \mathrm{~mm}$ thick) of cheese were tempered at $20^{\circ} \mathrm{C}$ for $15 \mathrm{~min}$, placed between the two parallel, serrated plates of the rheometer cell, equilibrated at $20^{\circ} \mathrm{C}$ for $3 \mathrm{~min}$ and subjected to a harmonic low amplitude shear strain $(\gamma)$ of 0.005 , at an angular frequency of $1 \mathrm{~Hz}$. The temperature was increased to $82^{\circ} \mathrm{C}$ at a rate of $3^{\circ} \mathrm{C} / \mathrm{min}$. The elastic shear modulus $\left(\mathbf{G}^{\prime}\right)$ and phase angle $(\delta)$ of the melting cheese were computed continuously during heating.

\section{Statistical Analysis}

A randomized complete block design, which incorporated the four treatments (CL, DA1, DA2, and DA3) and three blocks (replicate trials), were used to analyze the response variables relating to the composition of the cheese (Table 2). Analysis of variance (ANOVA) was carried out using a SAS procedure (SAS, 1995) where the effects of treatment and replicates were estimated for all response variables. Duncan's multiple-comparison test was used as a guide for pair comparisons of the treatment means. The level of significance was determined at $P<0.05$.

A split plot design was used to monitor the effects of treatment, storage time, and their interaction on the response variables measured at intervals during storage, i.e., pH, intact casein content, expressible serum, firmness, melt time, flowability, AV, and stretch. Analysis of variance for the split plot design was carried out using a general linear model procedure of SAS (1995). Statistically significant differences $(P<0.05)$ between different treatment levels were determined by Fisher's least significant difference.
The four cheeses from each trial were analyzed for microstructure at 1 and $14 \mathrm{~d}$, and for heat-induced changes in viscoelasticity at $1,5,12,20,35$, and $44 \mathrm{~d}$. The latter data are presented as supportive data but were not statistically analyzed.

Where firmness, melt time, flowability, and AV of the melted cheese were plotted as a function of intact casein, linear regression of data from all cheeses at all storage times was performed. The significance of the regressions was determined by applying Student's $t$ test to $\mathrm{r}^{2}$ with $n$-2 degrees of freedom (df), where $n$ is the actual number of data points.

\section{RESULTS AND DISCUSSION}

\section{Cheese-making}

The DA1 milk coagulated quite rapidly, forming a gel that was sufficiently firm to cut in $8.7 \mathrm{~min}$, compared with 39 to 44 min for the CL, DA2, and DA3 milks (Table 1). A similar effect has also been reported in other studies where the $\mathrm{pH}$ at setting was $\leq 6.0$ during the manufacture of Mozzarella cheese using DA or a combination of DA and starter cultures (Keller et al., 1974; Kindstedt and Guo, 1997a; Metzger et al., 2000). The rapid curd-forming properties of the DA1 milk are expected as the reduction in set $\mathrm{pH}$ leads to a reduction in the net charge on the casein micelles, an increase in the concentration of ionic calcium, and an increase in rennet activity (Walstra and Jenness, 1985; Fox et al., 2000).

Apart from the shorter coagulation time, the manufacture of the DA1 cheese was similar to that of the other cheeses, viz., the time and temperature profiles from setting of the milk to the cooling of the finished cheese (Table 1). 


\section{Gross Composition}

Data on the composition of the various cheeses are summarized in Table 2. Compared to the other cheeses, the DA1 cheese had a significantly lower level of protein, ash, and $\mathrm{Ca}$, and a higher level of moisture and moisturein-nonfat substances (MNFS). This effect concurs with the results of others (Keller et al., 1974; Metzger et al., 2000), who reported a reduction in the Ca content of cheese made from milk that had been preacidified before setting, to a degree depending on the extent of $\mathrm{pH}$ reduction at setting and whey drainage, and the type of acid used.

The low concentration of $\mathrm{Ca}$ in the DA1 cheese compared to the other cheeses, especially DA2, which was plasticized at the same $\mathrm{pH}$, may be attributed to the lower $\mathrm{pH}$ at setting and at whey drainage, which results in increased solubilization of micellar calcium phosphate (van Hooydonk et al., 1986) and a concomitant increase in the concentration of soluble $\mathrm{Ca}$ in the whey while in contact with the curds. The whey acts a vehicle in which the soluble $\mathrm{Ca}$ is removed from the curds at whey drainage. Moreover, for a given $\mathrm{pH}$ at whey drainage, a more rapid (all-at-once) acidification and solubilization of $\mathrm{Ca}$ (e.g., by preacidification) led to a greater loss of $\mathrm{Ca}$ in the whey and a lower concentration in the cheese (Czulak et al., 1969). After cutting, the curd particles (CP) develop a membrane (skin) which has a higher casein-to-fat ratio than the interior (Kalab, 1977) owing to loss of the fat from the surface layer (Fox et al., 2000). Presumably, the permeability of the $\mathrm{CP}$ as a whole, and especially the curd particle membrane (CPM), decreases with time between cutting and draining as a consequence of casein dehydration and/or the continuous loss of fat. The movement of $\mathrm{NaCl}$ in cheese moisture is a pseudo-diffusion process whereby movement is limited by, among other things, the sieving effect of the protein matrix through which the moisture permeates (Geurts et al., 1974a). It may be assumed that the movement of $\mathrm{Ca}$ through the curd particle to the bulk phase whey is similarly impeded by the sieving effect exerted by the protein matrix of the $\mathrm{CP}$, especially at the CPM. Thus, the extensive loss of $\mathrm{Ca}$ from the $\mathrm{CP}$ before reduced permeability is a limiting factor to its migration to the whey, and may in part account for the low concentration of $\mathrm{Ca}$ in rapidly acidified cheese. Hence, a reduction of $\mathrm{pH}$ before rennet coagulation, as for DA1, probably effects a more efficient removal of $\mathrm{Ca}$ from the curd than the slow reduction of $\mathrm{pH}$ after gelation and gel cutting, as in CL, DA2, and DA3. The similar concentration of $\mathrm{Ca}$ in the latter cheeses, despite the differences in plasticization $\mathrm{pH}$ and final $\mathrm{pH}$, was expected because of the similar $\mathrm{pH}$ at setting and at whey drainage, factors that are the major determi- nants of the total Ca content of cheese (Lawrence et al., 1984).

The higher moisture content of DA1 may be due to its relatively low Ca-to-casein ratio, which would be conducive to a greater degree of casein hydration. This result concurs with those of Shehata et al. (1967) and Keller et al. (1974), each of which showed a linear increase in the moisture content of DA Mozzarella as the Ca level in the cheese decreased. The inverse relationship between the moisture content of Mozzarella and Ca content is also consistent with the findings of model studies involving dilute suspensions of casein or para-casein, which have shown that casein hydration increases as the level of bound Ca decreases (Sood et al., 1979). Hence, as discussed below, the level of nonexpressible serum per gram of protein, which is an index of the degree of protein hydration, was significantly higher in DA1 than in the other cheeses throughout storage. Similarly, sequestration of $\mathrm{Ca}$ during the manufacture of processed cheese products, as effected by the addition of emulsifying salts, such as sodium phosphates, is accompanied by an increase in casein hydration (Fox et al., 2000). It is noteworthy that the moisture content of cheeses with similar $\mathrm{Ca}$ concentrations did not differ significantly.

In contrast to the results of the current study and those of Shehata et al. (1967) and Keller et al. (1974), Metzger et al. (2000) reported that the moisture content of reduced-fat Mozzarella was not significantly affected by varying the Ca level in the range 17.5 to $30.2 \mathrm{mg} / \mathrm{g}$ of protein. The discrepancy between the results of Metzger et al. (2000) and those of the other studies may be related to differences in the $\mathrm{pH}$ of the curd at stretching, which, in conjunction with $\mathrm{Ca}$ content, probably have a major effect on the hydration of the para-casein. Model studies on rennet-treated skim milk have shown that the hydration of casein micelles increases markedly as the $\mathrm{pH}$ is reduced from 6.0 to 5.4 but decreases markedly as the $\mathrm{pH}$ is reduced further toward the isoelectric $\mathrm{pH}$ (Creamer, 1985). The decrease in hydration at $\mathrm{pH}$ values $<5.4$ is probably a consequence of increased hydrophobic interactions, which are effected by a decrease in the net micellar charge due to increased concentrations of $\mathrm{H}^{+}$and $\mathrm{Ca}^{2+}$ (van Hooydonk et al., 1987; Guinee et al., 2000a). In the study of Metzger (2000), the control (high Ca, $30.2 \mathrm{mg} / \mathrm{g}$ of protein) cheese was salted at $\mathrm{pH} 5.5$, while the cheeses made using a combination of acid and starter culture (low $\mathrm{Ca}, 25.7$ to $17.8 \mathrm{mg} / \mathrm{g}$ of protein) were salted at $\mathrm{pH}$ 5.3. The $\mathrm{pH}$ at plasticization was probably somewhat lower as the $\mathrm{pH}$ usually decreases somewhat (typically 0.05 to $0.1 / \mathrm{U}$ over $20 \mathrm{~min}$ ) during mellowing, since salt diffusion to the center of curd chips is not instantaneous (Guinee and Fox, 1993), and hence, the growth of the starter culture is not immediately inhibited. Therefore, the $\mathrm{pH}$ of all cheeses at $1 \mathrm{~d}$ were similar at $\sim 5.23$, and 
at $15 \mathrm{~d}$ ranged from $\sim 5.15$ to 5.2 in the low-Ca cheeses to 5.3 in the CL cheese (Metzger et al., 2001). In the current study, the CL cheese (high $\mathrm{Ca}, 27.7 \mathrm{mg} / \mathrm{g}$ of protein) was salted at $\mathrm{pH} 5.3$, while the DA1 cheese (low $\mathrm{Ca}, 21.7 \mathrm{mg} / \mathrm{g}$ of protein) was salted at $\mathrm{pH} 5.6$; the $\mathrm{pH}$ of the CL and the DA1 at 1 was 5.42 and 5.96, respectively. Hence, the reduction in Ca level in the studies of Metzger et al. $(2000,2001)$ was not accompanied by an increase in moisture content probably because of the low $\mathrm{pH}$ of the curd during plasticization, which would offset the effects of lower Ca content on para-casein hydration.

The fat content of the CL cheese was significantly higher than that of the DA cheeses, which had a similar fat content. Moreover, the FDM level of the DA2 and DA3 cheeses was lower than that of the CL and DA1 cheeses, suggesting higher losses of fat to the cheese whey and/or the stretch water during the manufacture of the former cheeses. The fat level in the whey and stretch water was not measured in the current study; hence, no good explanation can be offered for the above trends for fat and FDM. The results of Metzger et al. (2000) showed that preacidification of milk may lead to an increase or a decrease in fat retention in DA cheeses, depending on the type of acid used and the degree of acidification. Further studies are needed to understand the means by which preacidification influences fat retention during the manufacture of DA cheese.

There was a decrease in the level of intact casein in all cheeses during storage (Figure 1); this trend coincided with an increase in the degree of proteolysis, which was described by Feeney et al. (2002). There was a significant effect of the interaction between make procedure and storage time on the level of intact casein (Table 3), with the levels for CL and DA1 being significantly lower than those for DA2 and DA3 at storage times $\geq 12 \mathrm{~d}$. The lower levels of intact casein in the former cheeses reflect the lower protein content and the higher degree of proteolysis (Feeney et al., 2002) in the DA1 cheeses.

\section{pH}

The mean $\mathrm{pH}$ of the DA1 and DA2 cheeses was significantly higher than that of the CL and DA3 cheeses, which were similar. The $\mathrm{pH}$ of all cheeses at $1 \mathrm{~d}$ was higher (by $\sim 0.3$ to 0.4 units) than that of the curd at milling (Table 1).

The relatively large increase in $\mathrm{pH}$ between milling and $\mathrm{d} 1$ is noteworthy. This trend has been observed repeatedly in Mozzarella cheesemaking trials at this laboratory and has also been reported by Guo et al. (1997). This increase in $\mathrm{pH}$ may be associated with a reduction in the lactate-to-protein ratio (Huffman and Kristofferson, 1984; Fox and Wallace, 1997) and a loss of buffering capacity of the curd (Czulak et al., 1969) due to removal

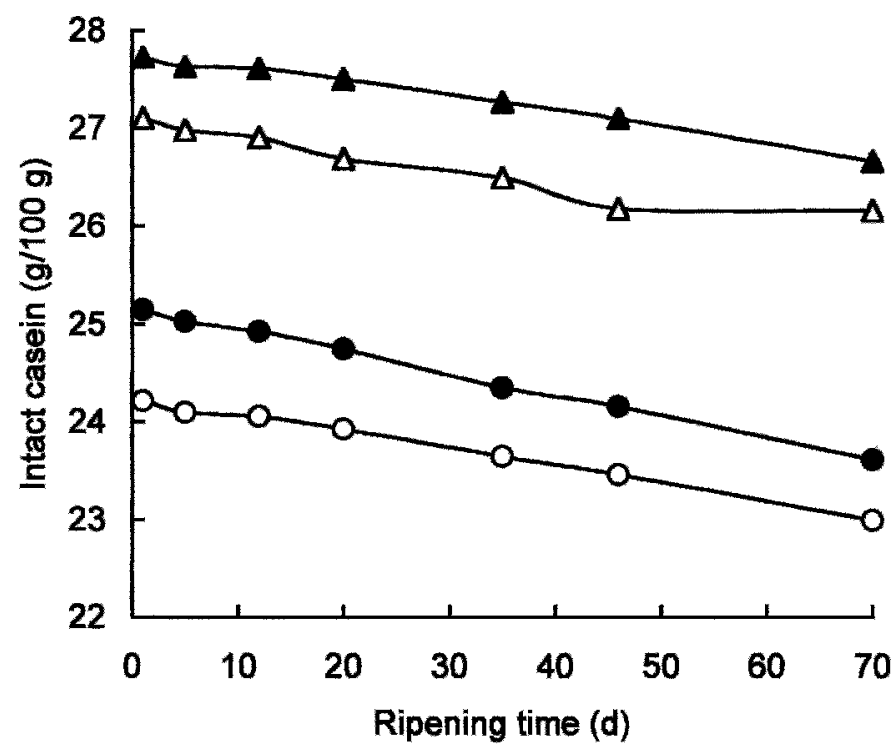

Figure 1. Age-related changes in the concentration of intact casein in Mozzarella cheese made using conventional acidification by starter culture $(\mathrm{CL}, \bullet)$ or direct acidification (DA1, $\bigcirc$; DA2, $\mathbf{\Delta} ; \mathrm{DA} 3, \triangle)$. The cheese-making procedure was altered to give cheeses of different $\mathrm{pH}$ and $\mathrm{Ca}$ level (mg/g protein): 5.42 and 27.7, (๑); 5.96 and 21.8, (O); 5.93 and 29.6, $(\mathbf{\Delta})$; and 5.58 and 28.7, $(\triangle)$. Details of make procedure and composition are given in the text. Values presented are the means from three replicate trials.

of lactic acid, soluble $\mathrm{Ca}$, and phosphate in the stretch water. Calcium phosphate is a major determinant of the buffering capacity of cheese, which increases as the $\mathrm{pH}$ is reduced in the region 6.0 to 5.1 (Lucey and Fox, 1993). Hence, reductions in the lactate-to-protein ratio and in the concentration of calcium phosphate, as occurs during plasticization, are conducive to an increase in $\mathrm{pH}$. Moreover, on subsequent cooling of the plasticized curd, micellar calcium phosphate dissolves and may result in an increase in $\mathrm{pH}$ due to inactivation of $\mathrm{H}^{+}$by the phosphate anion. Differences in the temperature of the curd at which the $\mathrm{pH}$ is measured probably also contributed to the increase in $\mathrm{pH}$ noted between milling (curd at $39^{\circ} \mathrm{C}$ ) and $1 \mathrm{~d}$ (curd at $21^{\circ} \mathrm{C}$ ), as it would affect the equilibrium concentrations of soluble and colloidal phosphate (Walstra and Jenness, 1985; Dagleish and Law, 1989). The $\mathrm{pH}$ of cheese curd at $21^{\circ} \mathrm{C}$ increases also as a result of salt addition, from $\sim 5.4$ at $0 \% \mathrm{wt} / \mathrm{wt}$ salt to 5.53 at $2.4 \% \mathrm{wt} /$ wt salt (Guinee, unpublished results).

In contrast to the above, the results of Metzger et al. (2001) indicate that the $\mathrm{pH}$ of plasticized curd at $1 \mathrm{~d}$ was lower ( 0.1 to $0.2 \mathrm{U}$ ) than that at salting. The discrepancies between the results of the current study and those of the latter may be attributable to differences in make procedure (i.e., differences in the ratio of stretch water to curd, salt content of the curd) that could affect the ratio of buffering substances (e.g., phosphate and protein) 


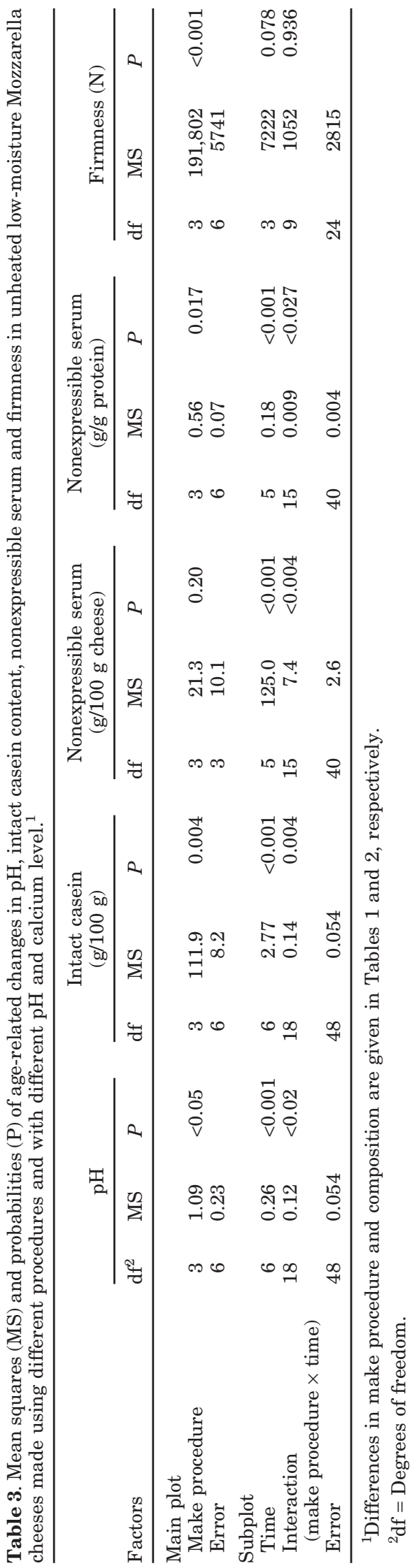

to lactate (Lucey and Fox, 1993). Further study is required on the factors that affect the $\mathrm{pH}$ of cheese curd.

The $\mathrm{pH}$ of the cheese increased gradually during storage, typically by $\sim 0.1$ to $0.16 \mathrm{U}$ at $70 \mathrm{~d}$ (Figure 1 ). There was a significant effect of the interaction between make procedure and storage time on $\mathrm{pH}$, with the rate of increase during storage being highest for the DA3 and DA4 cheeses and lowest for DA2 (Table 3, Figure 2). The increase in $\mathrm{pH}$ during storage was noted by Metzger et al. (2001) for low fat, and by Guo et al. (1997) for full fat in Mozzarella cheeses made using a starter culture. The increase in $\mathrm{pH}$ may be associated with the gradual increase in para-casein hydration and the increased availability of various protein residues (e.g., $\varepsilon$ - and $\alpha$-carboxyl groups of aspartic and glutamatic acids), which combine with $\mathrm{H}+$ during storage and thereby reduce the hydrogen ion activity of the moisture phase of the cheese. In turn, the increase in para-casein hydration may be affected by changes in the equilibrium concentrations of soluble and colloidal calcium phosphate (Guo et al., 1997), migration of salt in moisture in contact with the protein phase (e.g., ice structure water, imbibed water; Geurts et al., 1974a, b), and proteolysis.

\section{Expressible Serum}

The level of expressible serum has been used as an indirect measure of the water-holding capacity (WHC) of cheese, with a low level indicating a high WHC (Kindstedt, 1995; Kindstedt and Guo, 1997b). Conversely, the level of nonexpressible serum (NES) may be used as a more direct index of the WHC of the cheese matrix, with a high level indicating a high WHC. In the current study, the NES, which presumably has a lower water vapor pressure than ES during cooking of the cheese, was expressed as g/100 of cheese (NESC) or as g/g of cheese protein (NESP). In agreement with the results of previous studies, which showed a decrease in the level of expressible serum over time for Mozzarella (Kindstedt, 1995), both the NESC and NESP increased during storage, indicating an age-related increase in the WHC of the casein. The increased WHC of the curd is considered important, as it affects its ability to retain moisture and hence its ability to flow, stretch, and remain succulent during baking (Kindstedt, 1995; Kindstedt and Guo, 1997b).

The NESC was significantly affected by the interaction between make procedure and storage time (Figure 3a; Table 3), with the rate of increase being highest for CL and DA3. At most storage times $\geq 15 \mathrm{~d}$, the NESC of DA2 was significantly lower than that of DA3 and numerically lower than that of CL or DA1. At first approximation, it might be expected that the NESC would be highest in DA1, owing to its low calcium concentration and expected 


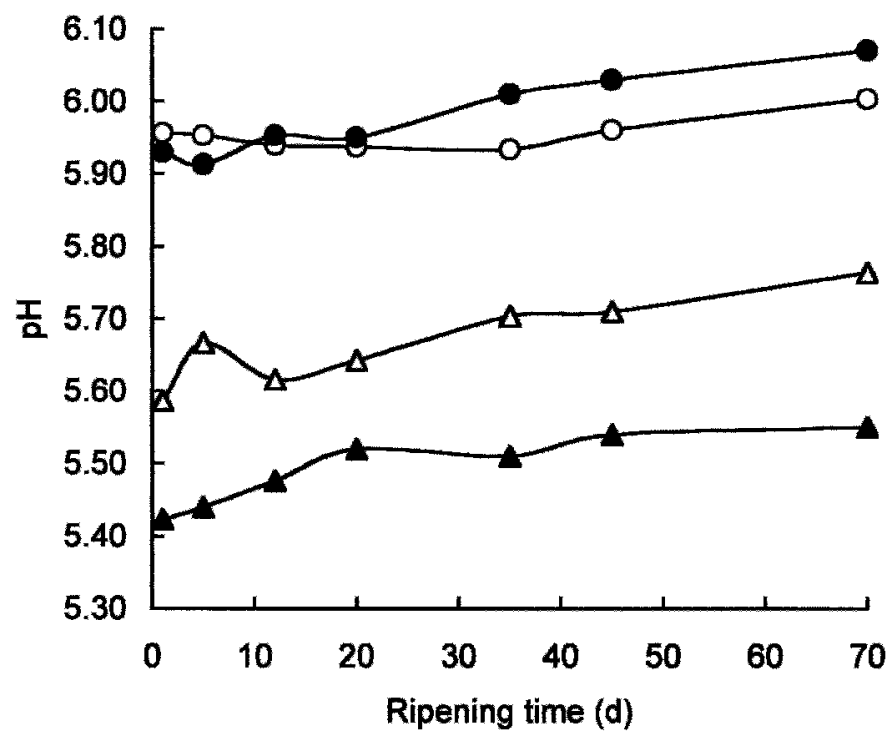

Figure 2. Age-related changes in $\mathrm{pH}$ of Mozzarella cheese made using conventional acidification by starter culture $(\mathrm{CL}, \bullet)$ or direct acidification (DA1, $\bigcirc ; \mathrm{DA} 2, \mathbf{\Delta} ; \mathrm{DA} 3, \triangle$ ). The cheese-making procedure was altered to give cheeses of different $\mathrm{pH}$ and $\mathrm{Ca}$ level (mg/g protein):

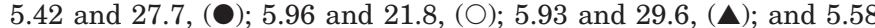
and $28.7,(\triangle)$. Details of make procedure and composition are given in the text. Values presented are the means from three replicate trials.

higher level of casein hydration (Sood et al., 1979). However, the protein content of the DA1 cheese was significantly lower than that of the other cheeses, a factor that would contribute to the relatively low level of NESC; the protein matrix is the main structural element responsible for holding the water (McMahon et al., 1999). The level of NESP in the DA1 was significantly higher than that in the other cheeses throughout storage, suggesting a higher WHC by its protein phase (Figure $3 b$ ). The NESP was significantly affected by the interaction between make procedure and storage time (Table 3 ), with the differences between DA1 and other cheeses decreasing during storage. While the NESP of DA2 did not differ significantly from that of CL or DA3, the level in DA2 was numerically lower at times $\geq 12 \mathrm{~d}$.

\section{Microstructure}

The spatial distribution of protein (Figures 4 a to $d$ and 5 a to $d$ ) and fat (Figures 4 e to $f$ and 5 e to f) in the cheeses from trial 1 at 1 and $20 \mathrm{~d}$ was clearly observed in the different micrographs as bright areas against a dark background; the micrographs of the cheeses from the other trials were similar (results not shown).

Longitudinal sections of CL, DA2, and DA3 at $1 \mathrm{~d}$ showed that protein formed the continuous phase and was in the form of linear fibers (Figure $4 a, c, d$ ). The fat occurred as discrete globules or elongated pools trapped
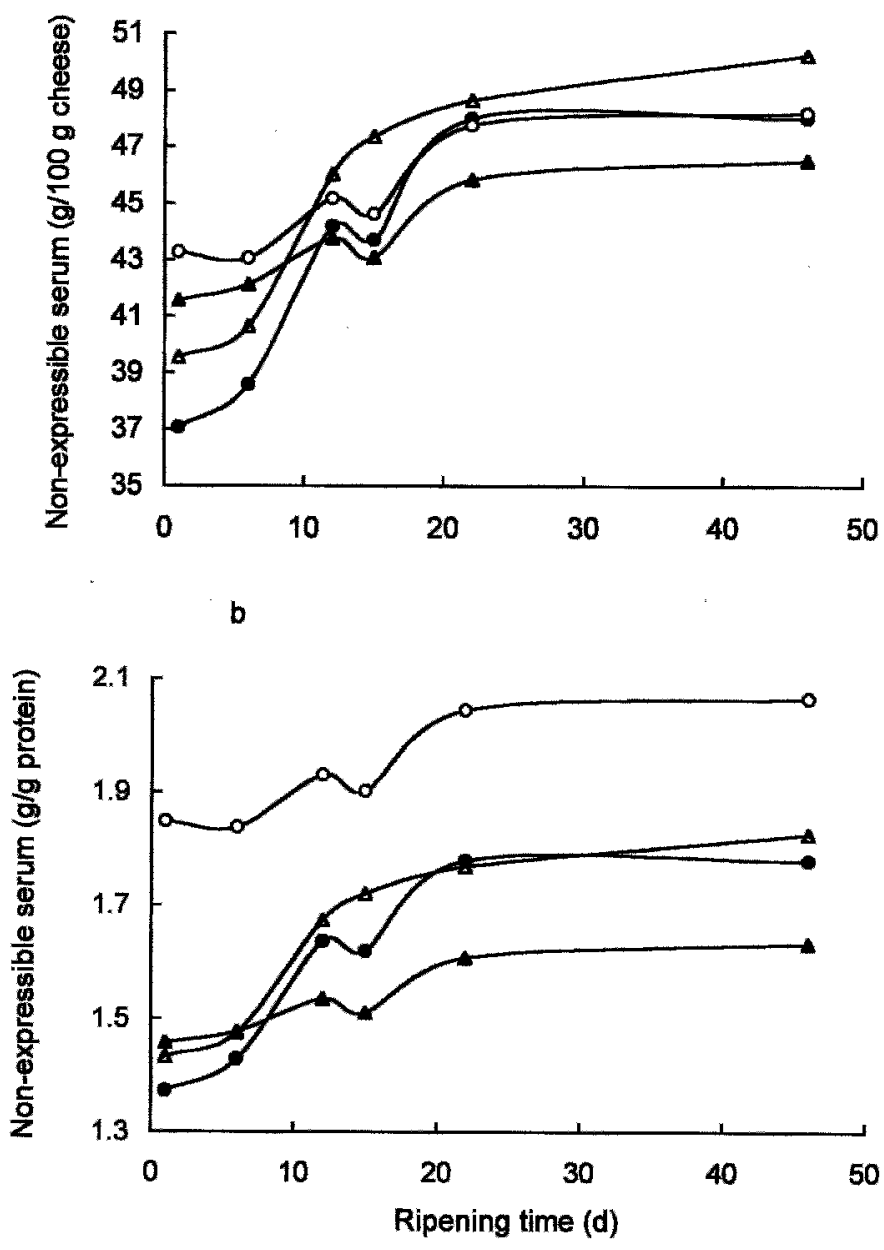

Figure 3. Age-related changes in the level of nonexpressible serum, expressed as $\mathrm{g} / 100 \mathrm{~g}$ of cheese (a) or as $\mathrm{g} / \mathrm{g}$ of protein (b) in Mozzarella cheese made using conventional acidification by starter culture $(\mathrm{CL}, \mathbf{\Theta})$ or direct acidification (DA1, O; DA2, $\mathbf{\Delta}$; DA3, $\triangle$ ). The cheese-making procedure was altered to give cheeses of different $\mathrm{pH}$ and $\mathrm{Ca}$ level (mg/g protein): 5.42 and 27.7, (๑); 5.96 and 21.8, (○); 5.93 and 29.6, $(\mathbf{\Delta})$; and 5.58 and 28.7, $(\triangle)$. Details of make procedure and composition are given in the text.

between the protein fibers (Figure 4e, g, h). The presence of elongated fat pools suggests the coalescence of denuded liquid fat droplets, probably formed as a consequence of damage to the fat globule membrane during curd manufacture and plasticization, while the curd is still warm. These microstructural observations are consistent with those found previously for Mozzarella and string cheeses using electron scanning (Taneya et al., 1992; McMahon et al., 1993, McMahon and Oberg, 1999) or confocal scanning laser microscopy (Guinee et al., 1999). Differences in staining intensity between individual fat globules/pools were observed as differences in gray level. These results may be related to differences in the interfacial properties of individual globules, for example, due to different degrees of damage to the fat globule membrane, which in 

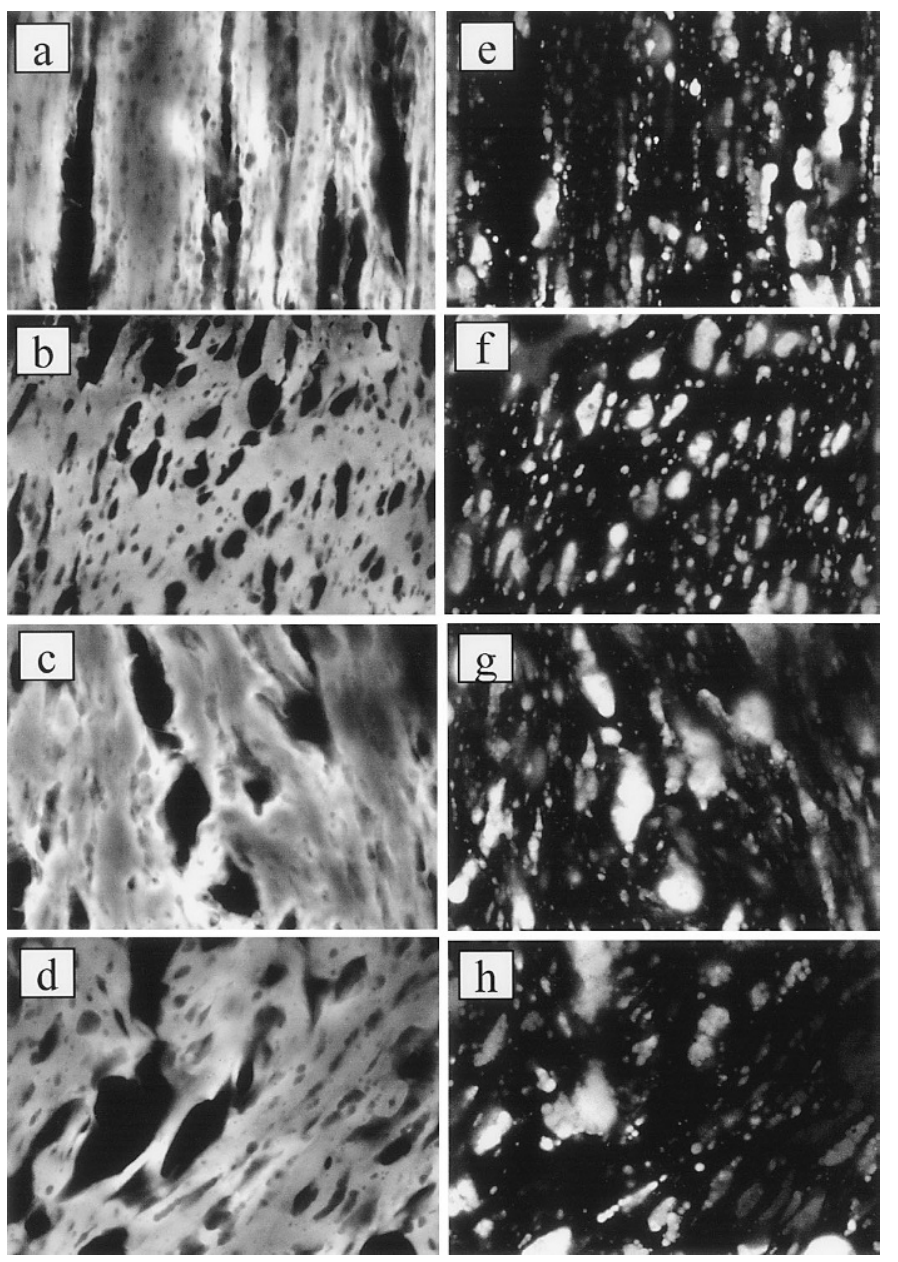

Figure 4. Confocal scanning laser micrographs showing protein (a to d) and fat (e to $\mathrm{h}$ ) as light areas against a dark background in 1-d-old, unheated Mozzarella cheeses made using conventional acidification by starter culture (a, e) or direct acidification (b to d, f to $\mathrm{g}$ ). The cheese-making procedure was altered to give cheeses of different $\mathrm{pH}$ and $\mathrm{Ca}$ level (mg/g of protein): 5.42 and 27.7, (CL; a, e); 5.96 and 21.8, (DA1; b, f); 5.93 and 29.6, (DA2; c, g); and 5.58 and 28.7, (DA3; d, h). Details of make procedure and composition are given in the text. Bar corresponds to $25 \mu \mathrm{m}$.

turn would cause variations in the extent of diffusion of the stain.

The microstructure of the 20-d-old CL, DA2, and DA3 cheeses indicated that during storage at $4^{\circ} \mathrm{C}$ there was a loss of identity of the protein fibers and a swelling of the protein matrix, which became more continuous. Concomitant with the change in the protein matrix, the fat was in the form of uniformly dispersed droplets and pools, which were generally smaller than those present at $1 \mathrm{~d}$. The swelling of the protein phase suggests an increase in protein hydration (Kindstedt and Guo, 1997b), and is consistent with increase in the NESP. The age-related transition to a more uniform distribution of fat droplets and pools suggests the swelling of the protein phase into regions previously occupied by fat and serum (Kindstedt and Guo, 1997b; McMahon et al., 1999; McMahon and Oberg, 1999).

At $1 \mathrm{~d}$, the microstructure of the DA1 cheese differed markedly from that of the other cheeses. The protein phase of the former was less fibrous and more swollen, with an appearance similar to that of the CL, DA2, and DA3 cheeses at $20 \mathrm{~d}$. Similarly, the fat particles in the DA1 cheese at $1 \mathrm{~d}$ appeared to be less elongated than those in the other cheeses at this time. The greater degree of protein swelling in the 1-d-old DA1 cheese is consistent with a greater degree of casein hydration, as reflected by its significantly higher NESP at $1 \mathrm{~d}$ (Figure 3 ). These observations are consistent with those of McMahon and Oberg (1999), who showed a reduction in the calcium content of Mozzarella led to a decrease in the number of pools of expressible serum and an increase in the volume fraction of the protein matrix.

After aging for $20 \mathrm{~d}$, the microstructural differences between the DA1 and other cheeses diminished, a trend which is consistent with the reduction in the differences in the magnitude of the NESP between the cheeses at times $>6 \mathrm{~d}$.

\section{Cheese Firmness}

While firmness was not significantly affected by storage time, there was a numerical decrease in the firmness of all cheeses during storage (Figure 6). The decrease, which concurs with the results of previous studies on Mozzarella (Yun et al., 1993; Guinee et al., 2000b), is consistent with the decrease in the content of intact casein (Guinee et al., 2000c).

The mean firmness over the storage period was significantly affected by make procedure, with that of the DA1 cheese being significantly lower than that of all the other cheeses; the mean firmness of the DA2 cheese was higher than that of the DA3 cheese. The low firmness of the DA1 cheese may be associated with its relatively low level of intact casein (Guinee et al., 2000c), high moisture content (Visser, 1991), low Ca content (Lawrence et al., 1984), and high degree of casein hydration. Regression analysis of the firmness versus time data for all the cheeses indicated a significant $(P<0.05)$ correlation between the level of intact casein and firmness $(\mathrm{df}=45 ; \mathrm{r}$ $=0.91$ ) and between the moisture content and firmness at any particular storage time ( $\mathrm{df}=10 ; \mathrm{r}=-0.85$ for firmness at $35 \mathrm{~d}$ ).

\section{Functionality of Heated Cheese}

The functional characteristics of the different cheeses changed during storage, the extent of the change being dependent on the make procedure (Figures 7 and 8). 


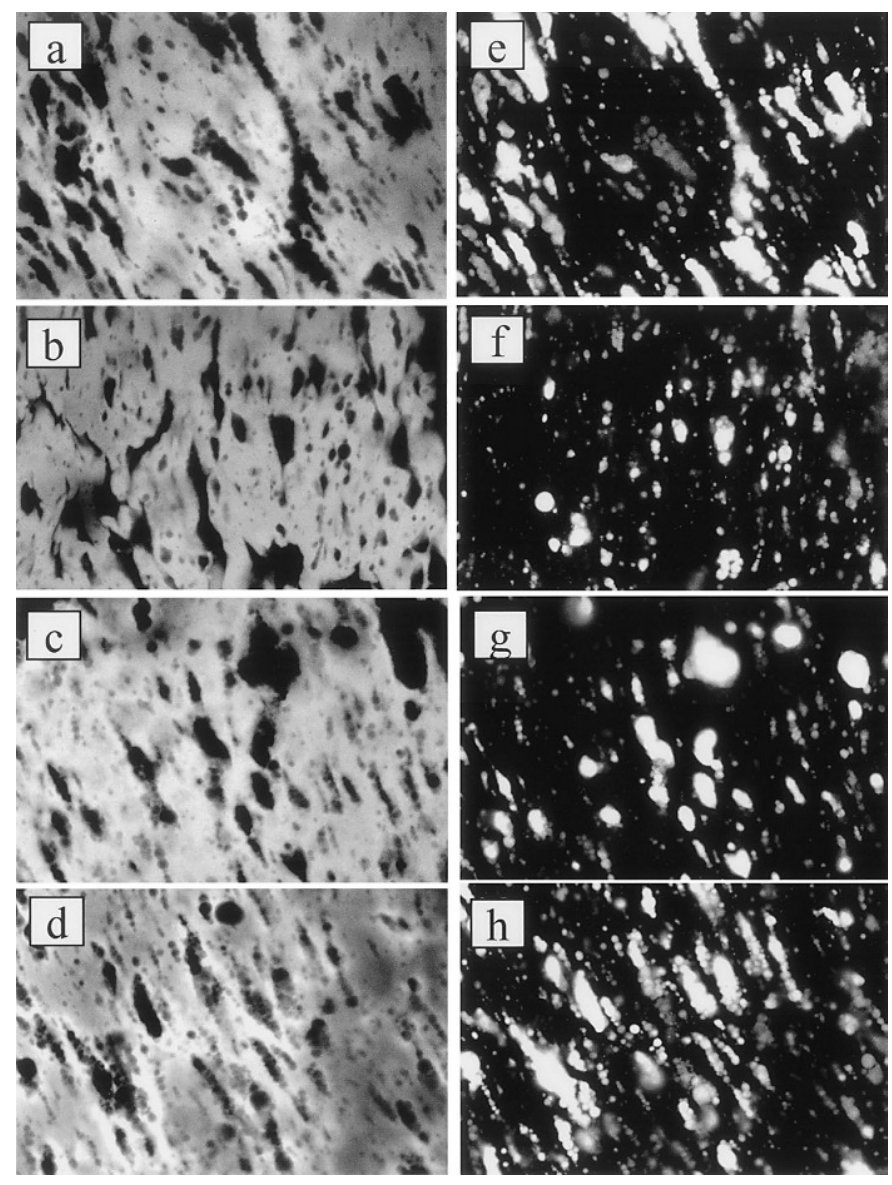

Figure 5. Confocal scanning laser micrographs showing protein (a to d) and fat (e to h) as light areas against a dark background in 20-d-old unheated Mozzarella cheeses made using conventional acidification by starter culture (a, e) or direct acidification (b to d, f to $\mathrm{g}$ ). The cheese-making procedure was altered to give cheeses of different $\mathrm{pH}$ and $\mathrm{Ca}$ level (mg/g protein): 5.42 and 27.7, (CL; a, e); 5.96 and 21.8, (DA1; b, f); 5.93 and 29.6, (DA2; c, g); and 5.58 and 28.7, (DA3; d, h). Details of make procedure and composition are given in the text. Bar corresponds to $25 \mu \mathrm{m}$.

Storage of the CL, DA1, and DA3 cheeses was paralleled by increases in flowability and stretchability and a reduction in melt time. In agreement with previous studies (Yun et al., 1993, 1995; Kindstedt, 1995; Guinee et al., $2000 \mathrm{~b}$ ), the AV of the CL, DA1, and DA3 cheeses decreased during storage. The AV of the DA2 cheeses exceeded the limit of the test method $(1000 \mathrm{~Pa} \cdot \mathrm{s})$ at all times and was markedly higher than that of the other cheeses at times $\geq 35 \mathrm{~d}$. The age-related decrease in AV may be attributed in part to the decrease in the concentration of intact para-casein (Figure 2) and the increased WHC of the casein (Kindstedt and Guo, 1997b; McMahon et al., 1999), as reflected by the increase in the NESP. Regression analysis of the data revealed significant linear relationships $(P<0.05)$ between the various functional parameters and the levels of NESP (Figure 9) and

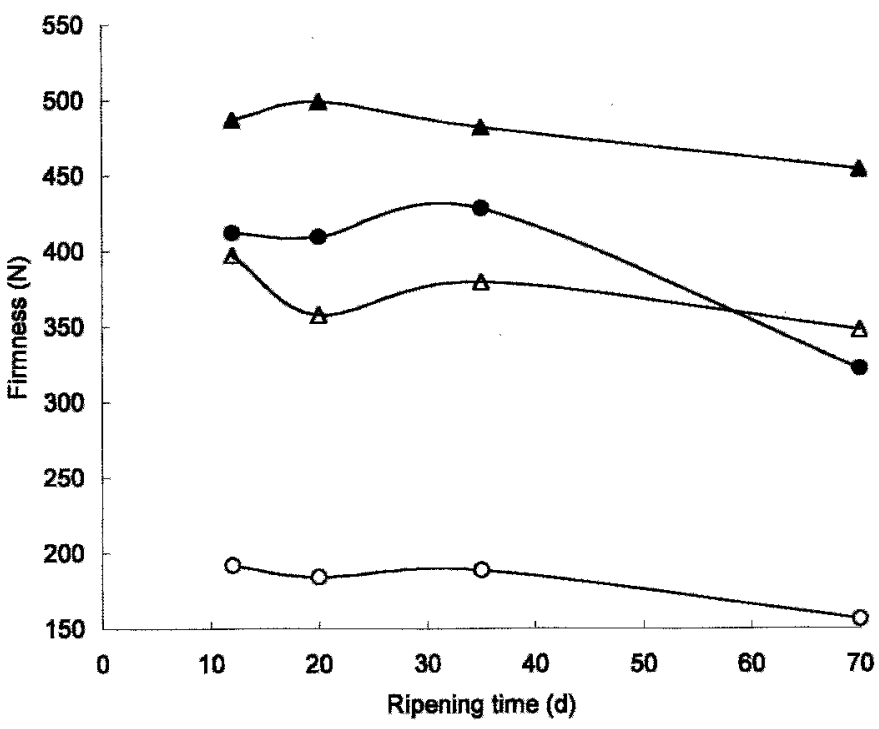

Figure 6. Age-related changes in the firmness of Mozzarella cheese made using conventional acidification by starter culture (CL, $\bullet$ ) or direct acidification (DA1, $\mathrm{O} ; \mathrm{DA} 2, \boldsymbol{\Delta} ; \mathrm{DA} 3, \triangle$ ). The cheese-making procedure was altered to give cheeses of different $\mathrm{pH}$ and Ca level (mg/g of protein): 5.42 and 27.7, ( ); 5.96 and 21.8, (○); 5.93 and 29.6, ( $\mathbf{\Delta})$, and 5.58 and 28.7, $(\triangle)$. Details of make procedure and composition are given in the text. Values presented are the means from three replicate trials.

intact casein (data not shown). The above trends also concur with those of others (Yun et al., 1993; Madsen and Qvist, 1998) who reported that increased proteolysis in Mozzarella cheese, via the use of rennet with strong proteolytic activity (e.g., Cryphonectria parasitica) or the addition of an exogenous proteinase (e.g., from Bacillus licheniformis or Bacillus subtilis), results in higher flowability and lower AV. The improvement in functionality that accompanies the increases in protein degradation and hydration, and the consequent decrease in protein aggregation, are expected as the flowability, stretchability, and AV of heated cheese may be considered as displacement of contiguous planes of the para-casein matrix.

There was a significant effect of the interaction between make procedure and storage time for flowability, stretchability, and melt time, as indicated by the decrease in the differences in the values of these functional attributes between the different cheeses over time (Table 4, Figures 7 and 8). The flowability of DA1 was higher than that of all other cheeses at storage times $\leq 5 \mathrm{~d}$, of DA3 at all times $\leq 46 \mathrm{~d}$, and of DA2 at all storage times. The flowability of DA1 at storage times $\leq 5 \mathrm{~d}$ was numerically similar to that of CL at 12 to $20 \mathrm{~d}$. The high flowability of DA1 at $\leq 5 \mathrm{~d}$ may be attributed to its relatively low level of protein (Guinee et al., 2000c), low calcium-tocasein ratio (Lawrence et al., 1984), high levels of moisture and MNFS (Rüegg et al., 1991), and NESP. Conversely, the low flowability and high $\mathrm{AV}$ of DA2 was 

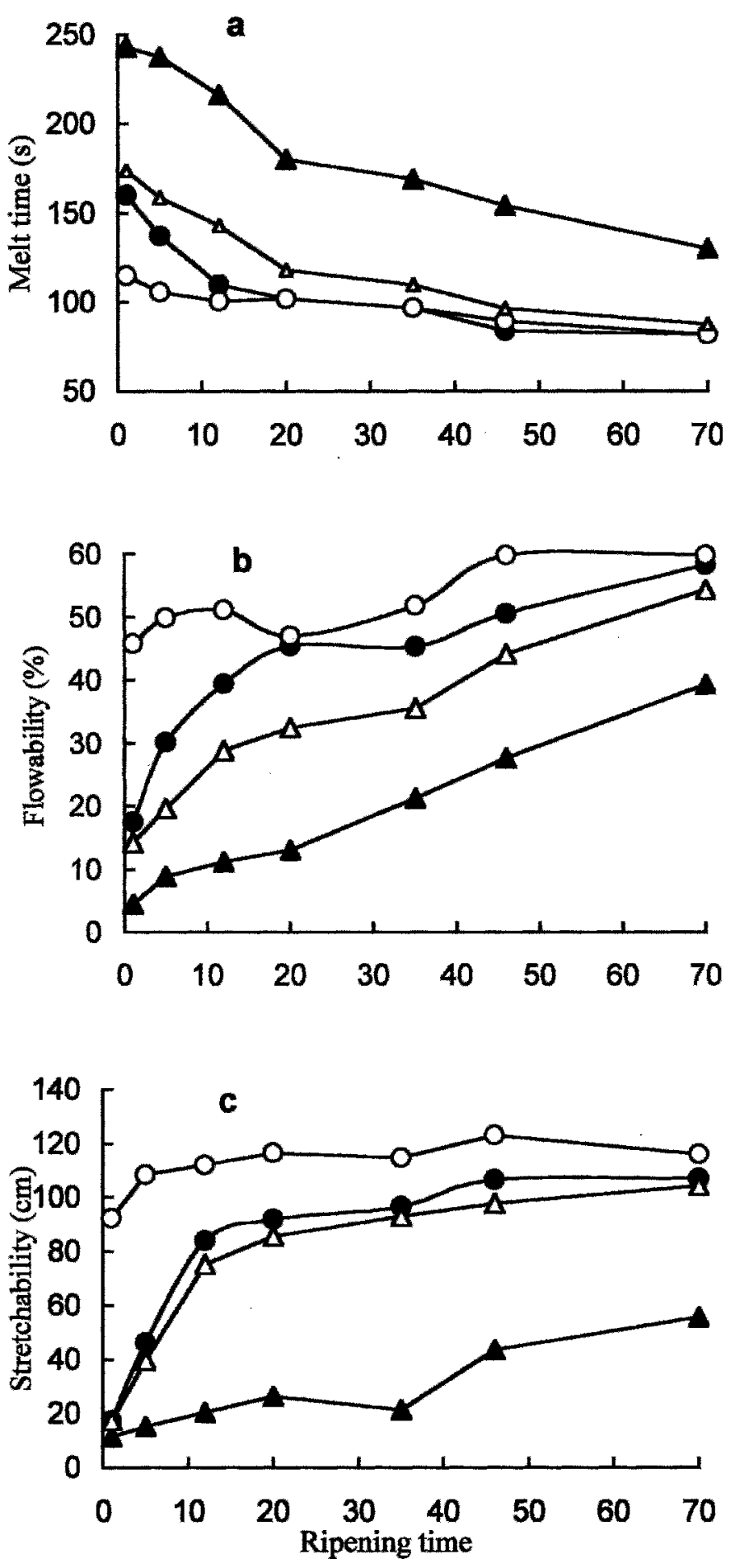

Figure 7. Age-related changes in the melt time (a), flowability (b), and stretchability (c) of Mozzarella cheese made using conventional acidification by starter culture (CL, $\mathbf{0}$ ) or direct acidification (DA1, $\mathrm{O} ; \mathrm{DA} 2, \mathbf{\Delta} ; \mathrm{DA} 3, \triangle)$. The cheese-making procedure was altered to give cheeses of different $\mathrm{pH}$ and $\mathrm{Ca}$ level $(\mathrm{mg} / \mathrm{g}$ protein): 5.42 and

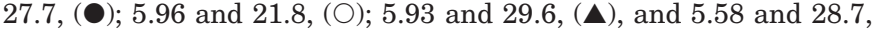
$(\triangle)$. Details of make procedure and composition are given in the text. Values presented are the means from three replicate trials.

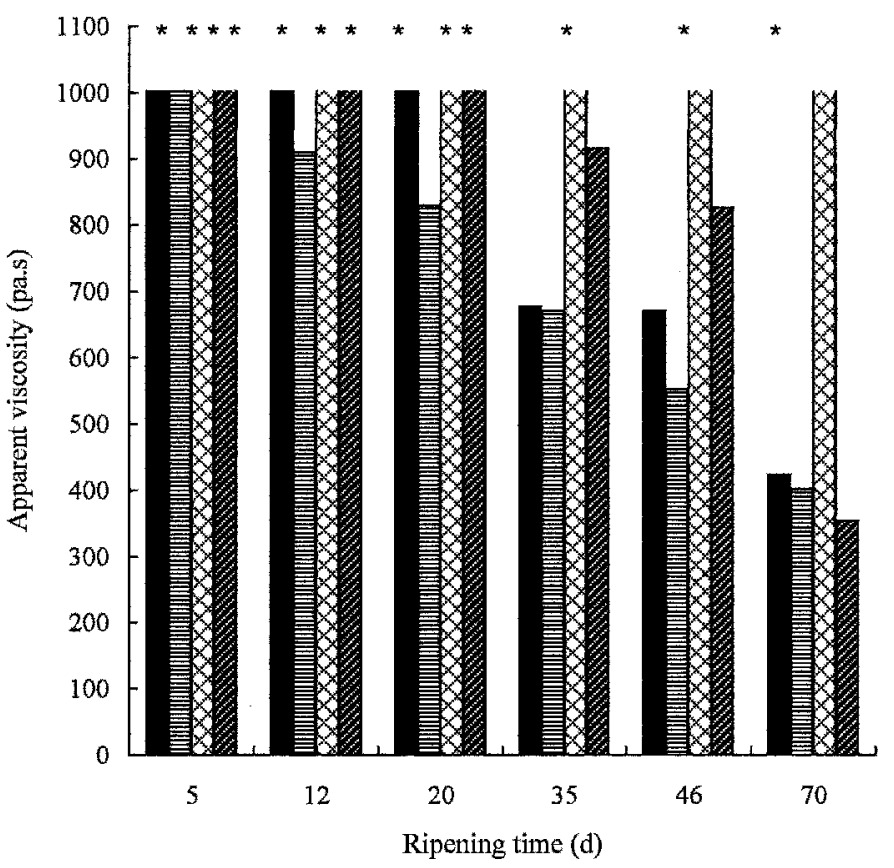

Figure 8. Age-related changes in the apparent viscosity of Mozzarella cheeses made using conventional acidification by starter culture $(\mathrm{CL}, \mathbf{\square})$ or direct acidification (DA1, striped; DA2, hatched; DA3, diagonal). The cheese-making procedure was altered to give cheeses of different $\mathrm{pH}$ and Ca level (mg/g protein): 5.42 and 27.7,(ष); 5.96 and 21.8, (striped); 5.93 and 29.6, (hatched); and 5.58 and 28.7, (diagonal). Values $>1000 \mathrm{~Pa}$ are indicated by an asterisk (*) at the top of the bar. Details of make procedure and composition are given in the text. Values presented are the means from three replicate trials.

probably associated with the combined effects of its high levels of intact casein and $\mathrm{Ca}$ and high $\mathrm{pH}$. The hydration of casein or para-casein in dilute solutions increases as the $\mathrm{pH}$ is reduced from 6.0 to 5.3 (Creamer, 1985). The low content of fat and FDM may also have contributed to the poor functionality of the DA2 cheese (Fife et al. 1996; Rudan et al. 1999; Guinee et al., 2000c).

Similar to the trend noted for flowability, the stretchability of DA1 was significantly higher than that of all other cheeses at times $\leq 5 \mathrm{~d}$, while that of DA2 was lower than that of all other cheeses at all storage times. The similar trends for the effect of make procedure on flowability and stretchability are expected since both parameters involve displacement of adjoining planes of the paracasein matrix. Hence, regression analysis of the age-related data from the three replicate trials showed a significant $(P<0.05)$, positive relationship between flow and stretchability ( $\mathrm{df}=58 ; \mathrm{r}=0.93$ ). In agreement with the trends noted for flow and stretch, the melt time of DA1 was lower than that of all other cheeses at storage times $\leq 5 \mathrm{~d}$, while that of the DA2 cheese was greater. 
Table 4. Mean squares (MS) and probabilities (P) of age-related changes in functional parameters of heated, low-moisture Mozzarella cheeses made using different procedures and with different $\mathrm{pH}$ and calcium level. ${ }^{1}$

\begin{tabular}{|c|c|c|c|c|c|c|c|c|c|}
\hline \multirow[b]{2}{*}{ Factors } & \multicolumn{3}{|c|}{ Melt time (s) } & \multicolumn{3}{|c|}{ Flow (\%) } & \multicolumn{3}{|c|}{ Stretch $(\mathrm{cm})$} \\
\hline & $\mathrm{df}$ & MS & $P$ & $\mathrm{df}$ & MS & $P$ & $\mathrm{df}$ & MS & $P$ \\
\hline \multicolumn{10}{|l|}{ Main plot } \\
\hline Make procedure & 3 & 34,847 & $<0.001$ & 3 & 4438 & $<0.001$ & 3 & 25,018 & $<0.001$ \\
\hline Error & 6 & 332 & & 6 & 171 & & 6 & 338 & \\
\hline \multicolumn{10}{|l|}{ Subplot } \\
\hline Time & 6 & 9632 & $<0.001$ & 6 & 1426 & $<0.001$ & 6 & 5832 & $<0.001$ \\
\hline $\begin{array}{l}\text { Interaction } \\
(\text { make procedure } \times \text { time })\end{array}$ & 18 & 648 & $<0.001$ & 18 & 68.3 & 0.008 & 18 & 613 & $<0.001$ \\
\hline Error & 48 & 199 & & 48 & 28.4 & & 48 & 119 & \\
\hline
\end{tabular}

${ }^{1}$ Differences in make procedure and composition are given in Tables 1 and 2, respectively.

${ }^{2} \mathrm{df}=$ Degrees of freedom.

\section{Changes in Viscoelasticity on Heating}

Changes in $\mathrm{G}^{\prime}$ and $\delta$ for the four cheeses, from trial 1 , at $1 \mathrm{~d}$ are shown in Figure 10; similar trends were noted at different storage times and for the cheeses from trials 2 and 3 (results not shown). Increasing the temperature of the cheese resulted in a decrease in $\mathrm{G}^{\prime}$ and an increase in $\delta$ for all cheeses, to an extent dependent on the make procedure. $\mathrm{G}^{\prime}$ decreased steeply, from a high at $20^{\circ} \mathrm{C}$ $\left(\mathrm{G}_{20}^{\prime}\right)$, as the temperature was raised to $\sim 45^{\circ} \mathrm{C}$, and thereafter more gradually, to a low at $80^{\circ} \mathrm{C}\left(\mathrm{G}_{80}^{\prime}\right)$. The initial decrease in $G^{\prime}$ indicates a softening of the cheese, an effect which was probably due mainly to liquefaction of the fat phase, which is fully liquid at $\sim 40^{\circ} \mathrm{C}$. In contrast, $\delta$ increased gradually from $\sim 15$ to $\sim 20$ to $25^{\circ}$ as the temperature was raised from 20 to $45^{\circ} \mathrm{C}$, and thereafter more steeply to a high value, $\delta_{80}$, ranging from $\sim 40$ to $70^{\circ}$, depending on the make procedure. The changes in $\mathrm{G}^{\prime}$ and $\delta$ marked a phase transition from an unheated cheese, which had a largely elastic rheological response $\left(\delta \sim 13\right.$ to $15^{\circ}$ at $\left.20^{\circ} \mathrm{C}\right)$, to a melted cheese, which is more fluid in character $\left(\delta \sim 40\right.$ to $60^{\circ}$ at $\left.80^{\circ} \mathrm{C}\right)$. These changes in viscoelasticity are similar to those previously reported for Cheddar and Mozzarella (Guinee et al., 1999).

Make procedure had a marked effect on the changes in $\mathrm{G}^{\prime}$ and $\delta$. DA1 had a relatively low $\mathrm{G}^{\prime}{ }_{20}$ and high $\delta_{80}$, especially at ripening times $<12 \mathrm{~d}$. The high value for $\delta$ indicates a high level of fluidity, which is consistent with the high flowability of this cheese at $12 \mathrm{~d}$. In contrast to DA1, DA2 had relatively high values of $\mathrm{G}_{20}^{\prime}$ and $\mathrm{G}_{80}^{\prime}$ and a markedly lower $\delta_{80}$. The heat-induced changes in viscoelasticity suggest that the structure of DA2 was altered to a lesser degree than that of the other cheeses on heating from 20 to $80^{\circ} \mathrm{C}$. The high value of $\mathrm{G}_{80}^{\prime}$ and low value of $\delta_{80}$ of DA2 concur with the low flowability of this cheese throughout storage. Previous studies have shown an inverse relationship between flow and $\mathrm{G}^{\prime}$ at $90^{\circ} \mathrm{C}$ for 4-mo-old Cheddar cheeses of varying fat content (Ustanol et al., 1994) and a direct relationship between flowability and $\delta$ at $100^{\circ} \mathrm{C}$ in analogue cheeses (Mounsey and O'Riordan, 1999).

The $\mathrm{G}^{\prime}$ versus time and $\delta$ versus time curves for the $\mathrm{CL}$ and DA3 cheeses were generally similar. The latter cheeses had values of $\mathrm{G}_{20}^{\prime}$ intermediate between those of the DA1 and DA2 cheeses, ${ }^{\prime}{ }_{80}$ values which were of similar magnitude ( $\sim 2$ to $3 \mathrm{kPa})$ to those of the DA1, and $\delta_{80}$ values which were similar to, or slightly lower than, those of DA1 cheese.

\section{CONCLUSIONS}

Mozzarella cheeses, which differed in Ca content and $\mathrm{pH}$, were made using a starter culture for the control cheese, CL, or by direct acidification of the milk with lactic acid (DA1 cheese), or by lactic acid and glucono- $\delta$ lactone (DA2 and DA3 cheeses). The study indicated that the $\mathrm{pH}$ at setting, whey drainage, and curd plasticization had a marked influence on cheese composition $(\mathrm{pH}, \mathrm{Ca}$ content, moisture level), level of NESP, WHC of the paracasein matrix, heat-induced changes in viscoelasticity, and storage-related changes in the functionality of the heated cheese. The DA1 cheese, which had a high $\mathrm{pH}$ (5.9) and a low Ca concentration ( $22 \mathrm{mg} / \mathrm{g}$ protein), had low levels of total protein (and, therefore, low levels of intact casein), and high levels of moisture, MNFS, and NESP. These characteristics of the DA1 cheese resulted in it having high initial values of flowability and stretchability at $1 \mathrm{~d}$ that were comparable to those attained by the control cheese that had been aged for $\sim 15 \mathrm{~d}$.

In contrast, raising the $\mathrm{pH}$ of Mozzarella with typical levels of $\mathrm{Ca}(\sim 29 \mathrm{mg} / \mathrm{g}$ protein) and moisture $(\sim 49 \%$, wt/ wt), from 5.42 or 5.58 , as in CL and DA3, respectively, to 5.93 , as in DA2, resulted in significantly lower values of flowability and stretchability at storage times $\geq 1 \mathrm{~d}$.

The results of a recent survey (Guinee et al., 2000a) indicated that each of the different functional attributes of commercial Mozzarella fall within a range of values, e.g., flowability, 43 to $68 \%$; stretchability, 56 to $134 \mathrm{~cm}$. 

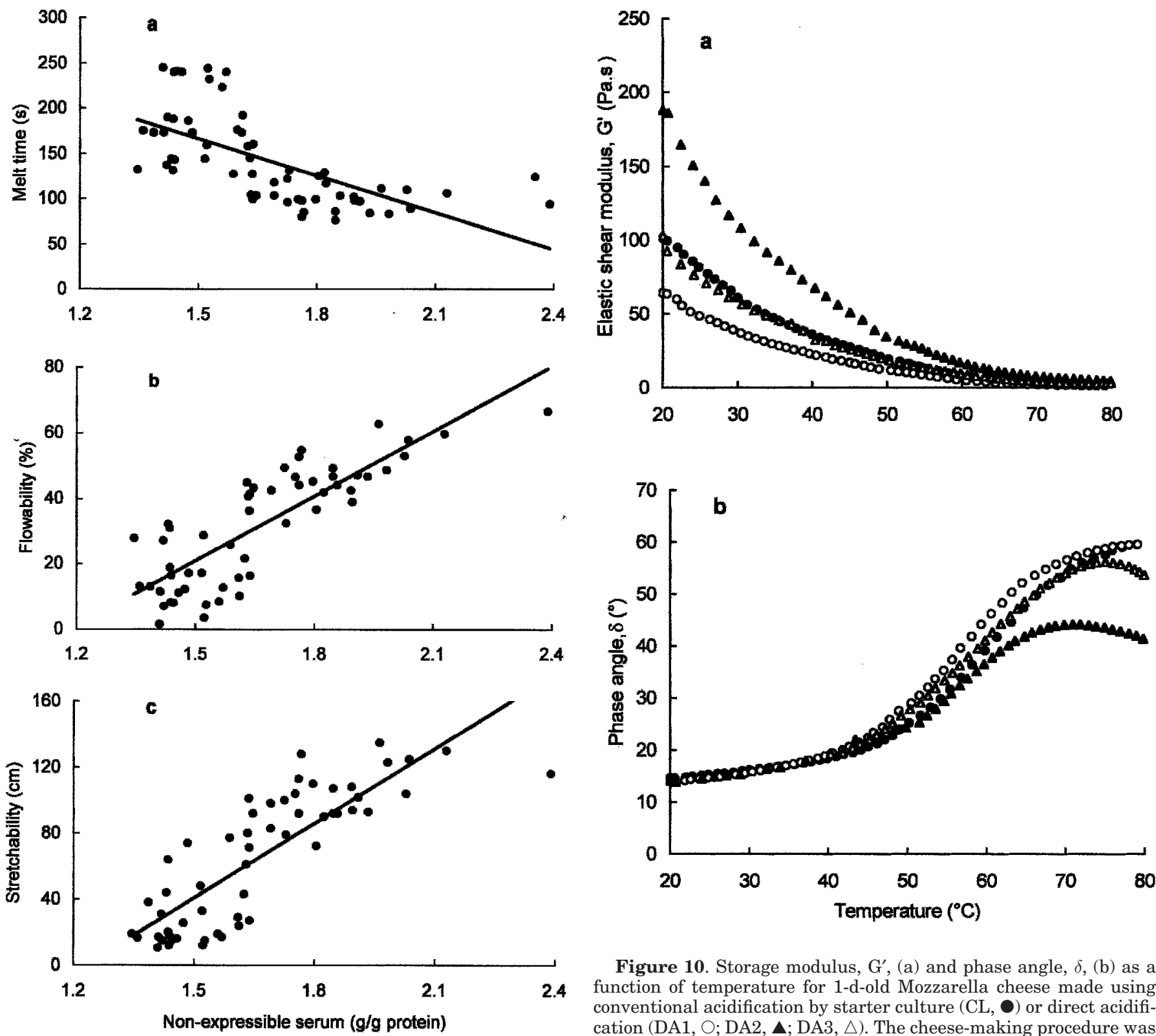

Figure 10. Storage modulus, $\mathrm{G}^{\prime}$, (a) and phase angle, $\delta$, (b) as a function of temperature for 1-d-old Mozzarella cheese made using conventional acidification by starter culture $(\mathrm{CL}, \bullet)$ or direct acidification (DA1, $\bigcirc$; DA2, $\mathbf{\Delta}$; DA3, $\triangle$ ). The cheese-making procedure was altered to give cheeses of different $\mathrm{pH}$ and $\mathrm{Ca}$ level ( $\mathrm{mg} / \mathrm{g}$ of protein):

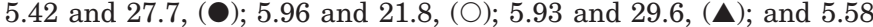
and 28.7, $(\triangle)$. Details of make procedure and composition are given in the text.

Felationship between levels of nonexpressible stretchability (c). The data were obtained from Mozzarella cheeses with different $\mathrm{pH}$ and $\mathrm{Ca}$ level made using conventional acidification by starter culture or direct acidification and stored at $4^{\circ} \mathrm{C}$ over a 70 $\mathrm{d}$ ripening period; regression lines with intercept shown. Regression was significant $(P<0.05)$ in all cases.

nient means by which the functional shelf life of Mozzarella cheese can be varied.

\section{ACKNOWLEDGMENTS}

The results of the current study showed that Ca content and $\mathrm{pH}$ markedly influenced the time required for each functional attribute to attain values typical of commercial Mozzarella, i.e., CL, DA1, and DA2 acquired a flowability of $43 \%$ after storage for 19,1 , and $79 \mathrm{~d}$, respectively. Thus, alteration of $\mathrm{pH}$ and Ca concentration is a conve-

This research was part funded by European Union Structural Funds (European Regional Development Fund). The authors kindly acknowledge the technical assistance of C. Mullins, M. O. Corcoran, and E. O. Mulholland, and B. T. O'Kennedy for his valuable comments and suggestions. 


\section{REFERENCES}

Creamer, L. K. 1985. Water absorption by renneted casein micelles. Milchwissenschaft 40:589-591.

Czulak, J., J. Conochie, B. J. Sutherland, and H. J. M. van Leeuwen. 1969. Lactose, lactic acid, and mineral equilibria in Cheddar cheese manufacture. J. Dairy Res. 36:93-101.

Dagleish, D. G., and A. J. R. Law. 1989. pH-induced dissociation of bovine casein micelles. II. Mineral solubilization and its relation to casein release. J. Dairy Res. 56:727-735.

Feeney E. P., P. F. Fox, and T. P. Guinee. 2002. Effect of $\mathrm{pH}$ and calcium level on the proteolysis in Mozzarella cheese. J. Dairy Sci. 85:1646-1654.

Fife, L. F., D. J. McMahon, and C. J. Oberg. 1996. Functionality of low-fat Mozzarella cheese. J. Dairy Sci. 79:1903-1910.

Fox, P. F., and J. M. Wallace. 1997. Formation of flavour compounds in cheese. Adv. Appl. Microbiol. 45:17-85.

Fox, P. F., T. P. Guinee, T. M. Cogan, and P. L. H. McSweeney. 2000. Fundamentals of Cheese Science. Aspen Publishers, Inc., Gaithersburg, MD.

Geurts, T. J., P. Walstra, and H. Mulder. 1974a. Transport of salt and water during salting of cheese. 1 . Analysis of the processes involved. Neth. Milk Dairy J. 28:102-129.

Geurts, T. J., P. Walstra, and H. Mulder. 1974b. Water binding to milk protein, with particular reference to cheese. Neth. Milk Dairy J. $28: 46-72$.

Guinee, T. P., M. A. E. Auty, and C. Mullins. 1999. Observations on the microstructure and heat-induced changes in the viscoelasticity of commercial cheeses. Aust. J. Dairy Technol. 54:84-89.

Guinee, T. P., D. Harrington, M. O. Corcoran, E. O. Mulholland, and C. Mullins. 2000a. The composition and functional properties of commercial Mozzarella, Cheddar, and analogue pizza cheese. Int. J. Dairy Technol. 53:51-56.

Guinee, T. P., E. O. Mulholland, C. Mullins, and M. O. Corcoran. 2000b. Effect of salting method on the composition, yield, and functionality of low-moisture Mozzarella cheese. Milchwissenschaft. 55:135-138.

Guinee, T. P., M. A. E. Auty, and M. A. Fenelon. 2000c. The effect of fat on the rheology, microstructure, and heat-induced functional characteristics of Cheddar cheese. Int. Dairy J. 10:277-288.

Guo, M. R., J. K. A. Gilmore, P. S. Kindstedt. 1997. Effect of sodium chloride on the serum phase of Mozzarella cheese. J. Dairy Sci. 80:3092-3098.

Huffman, L. H., and T. Kristofferson. 1984. Role of lactose in Cheddar cheese manufacturing and ripening. N.Z. J. Dairy Sci. Technol. 19:151-162.

Kalab, M. 1977. Milk gel structure. VI. Cheese texture and microstructure. Milchwissenschaft. 32:449-457.

Keller, B., N. F. Olson, and T. Richardson. 1974. Mineral retention and rheological properties of Mozzarella cheese made by direct acidification. J. Dairy Sci. 57:174-180.

Kimura, T., Y. Sagara, M. Fukushima, and S. Taneya. 1992. Effect of pH on the submicroscopic structure of string cheese. Milchwissenschaft $47: 547-552$

Kindstedt, P. S. 1995. Factors affecting the functional characteristics of unmelted and melted Mozzarella cheese. Pages 27-41 in Chemistry of Structure-Function Relationships in Cheese. E. L. Malin and M. H. Tunick, eds. Plenum Press, New York and London.

Kindstedt, P. S., and M. R. Guo, 1997a. Chemically-acidified pizza cheese: production and functionality. Pages 24-30 in 5th Cheese Symp. T. M. Cogan, P. F. Fox, and P. Ross, eds. Teagasc, Sandymount Avenue, Dublin, Ireland.

Kindstedt, P. S., and M. R. Guo. 1997b. Recent developments in the science and technology of pizza cheese. Aust. J. Dairy Technol. $52: 41-43$.
Lawrence, R. C. 1989. The use of ultrafiltration technology in cheesemaking. Pages 2-15 in Bulletin 240, Int. Dairy Fed. Brussels, Belgium.

Lawrence, R. C., H. A. Heap, and J. Gilles. 1984. A controlled approach to cheese technology. J. Dairy Sci. 67:1632-1645.

Lucey, J. A., and P. F. Fox. 1993. Importance of calcium and phosphate in cheese manufacture: A review. J. Dairy Sci. 76:1714-1724.

Madsen, J. S., and K. B. Qvist. 1998. The effect of enzymes on meltability of Mozzarella cheese manufactured by ultrafiltration. Lait 78:259-272.

McMahon, D. J., C. J. Oberg, and W. McManus. 1993. Functionality of Mozzarella cheese. Aust. J. Dairy Technol. 48:99-104.

McMahon, D. J., R. L. Fife, and C. J. Oberg. 1999. Water partitioning in Mozzarella cheese and its relationship to cheese meltability. J. Dairy Sci. 82:1361-1369.

McMahon, D., and C. Oberg. 1999. Deconstructing Mozzarella. Dairy Ind. Int. 64(7):23, 25-26.

Metzger, L. E., D. M. Barbano, M. A. Rudan, and P. S. Kindstedt. 2000a. Effect of milk preacidification on low-fat Mozzarella cheese. I. Composition and yield. J. Dairy Sci. 83:648-658.

Metzger, L. E., D. M. Barbano, P. S. Kindstedt, and M. R. Guo. 2000b. Effect of milk preacidification on low-fat Mozzarella cheese. I. Chemical and functional properties during storage. J. Dairy Sci. 83:1348-1356

Mounsey, J. S., and E. D. O'Riordan. 1999. Empirical and dynamic rheological data correlation to characterize melt characteristics of imitation cheese. J. Food Sci. 64:701-703.

Rowney, M., P. Roupas, M. W. Hickey, and D. W. Everett. 1999. Factors affecting the functionality of Mozzarella cheese. Aust. J. Dairy Technol. 54:94-102.

Rudan, M. A., D. M. Barbano, J. J. Yun, and P. S. Kindstedt. 1999. Effect of fat reduction on chemical composition, proteolysis, functionality, and yield of Mozzarella cheese. J. Dairy Sci. 82:661-672.

Rüegg, M., P. Eberhard, L. M. Popplewell, and M. Peleg. 1991. Melting properties of cheese. Pages 36-43 in Bulletin 268. Int. Dairy Fed. Brussels, Belgium.

SAS User's Guide: Statistics, Version 6.12 Edition. 1995. SAS Inst., Inc., Cary, NC.

Sood, V. K., D. K. Gaind, and R. K. Dewan. 1979. Correlation between micelle solvation and calcium content. N.Z. J. Dairy Sci. Technol. 14:32-34.

Sørensen, H. H. 1997. The World Market for Cheese. Pages 8-17 in Bulletin 326. Int. Dairy Fed. Brussels, Belgium.

Taneya, S., T. Izutsu, T. Kimura, and T. Shioya. 1992. Structure and rheology of string cheese. Food Struct. 11:61-71.

Ustanol, Z., K. Kawachi, and J. Steffe. 1994. Arnott test correlates with dynamic rheological properties for determining Cheddar cheese meltability. J. Food Sci. 59:970-971.

van Hooydonk, A. C. M., H. G. Hagedoorn, and I. J. Boerrigter. 1986. $\mathrm{pH}$-induced physico-chemical changes of casein micelles in milk and their effect on renneting. 1. Effect of acidification on physicochemical properties. Neth. Milk Dairy J. 40:281-296.

Visser, J. 1991. Factors affecting the rheological and fracture properties of hard and semi-hard cheese. Pages 49-61 in Bulletin 268. Int. Dairy Fed. Brussels, Belgium.

Walstra, P., and R. Jenness. 1985. Dairy Chemistry and Physics. John Wiley \& Sons, New York.

Yun, J. J., L. J. Kiely, P. S. Kindstedt, and D. M. Barbano. 1993. Mozzarella cheese: impact of coagulant type on functional properties. J. Dairy Sci. 76:3657-3663.

Yun, J. J., D. M. Barbano, P. S. Kindstedt, and K. L. Larose. 1995. Mozzarella cheese: impact of whey $\mathrm{pH}$ at draining on chemical composition, proteolysis, and functional properties. J. Dairy Sci. $78: 1-7$. 